\title{
ラット腹腔マクロファージの $\mathrm{PAF}$ 産生の調節機構 \\ ——特に 5-lipoxygenase 代謝産物の影響——
}

\author{
田村 泰・斉藤博幸・平井愛山・吉田 尚*
}

\begin{abstract}
Regulatory mechanism of $P A F$ synthesis in rat peritoneal macrophage-effect of 5-lipoxygenase metabolitesTai Tamura - Hiroyuki Saito • Aizan Hirai - Syo Yohsida*
\end{abstract}

platelet activating factor (PAF) は, macrophage, basophil, 多核好中球より離遊される強力な chemical mediator である。 その構造式は，1-0-alkyl-2-0-acetylsn-glycero-3-phosphocholine (alkyl-acetyl-GPC) であ $り^{1)}$ ，膜リン脂質より arachidonic acid (AA) とともに 遊離される alkyl-lyso GPC より合成される。近年 alkylacetyl-GPC より惹起される白血球凝集, 白血球膜顆粒 に $\mathrm{LTB}_{4}$ が関与しているといわれてお り ${ }^{2,3)}$, さら に 5-lipoxygenase 代謝産物である 5-hydroproxy-eicosatetraenoic acid (5-HPETE) 5-hydroxy eicosatetraenoic acid (5-HETE) が膜リン脂質からの AA の遊離を促進 するとの報告がみられる4).

以上の事実より 5-lipoxygenase 代謝産物である5HPETE，5-HETE および $\mathrm{LTB}_{4}$ が alkyl-acetyl-GPC 合 成機序にいかなる影響をもつかをみるためにラット腹腔 マクロファージを用いて検討した。

\section{材料と方法}

(1) ラット腹腔マクロファージの調整法は既往のと抒 りに施行した5).

(2) 5-HPETEはTeraoの法6)によりAA の hemoglobin catalysis によって合成し, Tri Rotor V chromatograph を使用して高速液体 chromatography によって精製し た. 5-HETE は $\mathrm{NaBH}_{4}$ によって 5-HEPETE を還元し て作製，さらに高速液体 chromatography によって精 製した。精製した 5-HEPETE および 5-HETE の純度 は95\%以上であった。 5-HETE の同定は GCMS によ って行った.

(3) Ca-ionophore A 23187 で刺激し産生されたラッ ト膜腔マクロファージでの 12-lipoxygenase 代謝産物, HETE, 11-HETE, 12-HETE, $\mathrm{LTB}_{4}$ の分析は高速液体 chromatography によって施行した。

(4) A 23187 で刺激したラット腹腔マクロファージで の ${ }^{14} \mathrm{C}$-alkyl-acetyl GPC の産生：採取したラット腹腔マ クロファージを $1 \mu \mathrm{Ci}{ }^{14} \mathrm{C}$-alkyl-lyso-GPC で incubate し, ${ }^{14} \mathrm{C}$-alkyl-acyl-GPC 標識マクロファージを作製した7). この標識マクロファージに種々の濃度のアラキドン酸カ スケード阻害剤や 5-HPETE，5-HETE をたは $\mathrm{LTB}_{4}$ を加え, $1 \mathrm{mMCaCl}_{2}, 0.1 \mathrm{mM}$ sodium acetate の存在下 で Ca-ionophore A 23187, $1 \mu \mathrm{M}$ で刺激した。産生さ

* The Second Department of Internal Medicine, Chiba University School of Medicine 千葉大 学医学部第二内科学教室
れた ${ }^{14} \mathrm{C}$-phospholipid $\left({ }^{14} \mathrm{C}\right.$-alkyl-acetyl-GPC, ${ }^{14} \mathrm{C}$-alkyllyso-GPC および ${ }^{14} \mathrm{C}$-alkyl-acyl-GPC) は Bligh and Dyer の法 $^{8)}$ に準じて抽出し, silica TLC film plate に 展開し, radioactive products は標準品および autoradiography で同定し，各代謝産物の spotを切り取り，液 体シンチレーションカウンターにて放射活性を測定し た。

\section{成 績}

標識したラット腹腔マクロファージを A 23187 で刺 激すると, ${ }^{14} \mathrm{C}$-alkyl-acetyl-GPC の産生は用量依存性に 増加し，それとともに ${ }^{14} \mathrm{C}$-alkyl-acyl-GPC の減少, ${ }^{14} \mathrm{C}$ alkyl-lyso-GPC の増加がみられた。A 23187 刺激による ${ }^{14} \mathrm{C}$-alkyl-acetyl-GPC 産生は, phospholipase $\mathrm{A}_{2}$ 阻害剂 である bromophenacyl bromide (BPB) の前処置によ り用量依存性に減少し, 逆に ${ }^{14} \mathrm{C}$-alkyl-acyl-GPC の増 加， ${ }^{14}$ C-alkyl-lyso-GPC の 増加をもたらした． A 23187 刺激のラット腹腔マクロファージに, 5-lipoxygenase の 特異的阻害剂である AA-861 を添加すると用量依存性 に ${ }^{14} \mathrm{C}$-alkyl-acetyl-GPC および ${ }^{14} \mathrm{C}$-alkyl-lyso-GPC の 産生を抑制し, 代わって ${ }^{14} \mathrm{C}$-alkyl-acyl-GPC の分解を 抑制した。一方 indomethacin の添加では，なんの影 響もみられなかった（図 1).

A 23187 刺激のマクロファージでの lipoxygenase 代 謝産物を高速液体 chromatography で分析したところ, 主要な代謝産物は 5-HETE， LTB 4 であり，AA-861 は 5-HETE, $\mathrm{LTB}_{4}$ の産生を特異的に抑制した。

逆に AA-861 で特異的に抑制された ${ }^{14} \mathrm{C}$-alkyl-acetylGPC の産生は， 5-HPETE および 5-HETE を外因性 に添加することにより用量依存性に回復した。しかし $\mathrm{LTB}_{4}$ にはそのよらな作用はみられなかった，5-HPETE のほうが 5-HETE よりもより強力に回復させた（図 2).

さらに A 23187 刺激の 標識マクロファージに外因症 に 5-HPETE または 5-HETE を添加すると, ${ }^{14} \mathrm{C}$-alkylacetyl-GPC および ${ }^{14} \mathrm{C}$-alkyl-lyso-GPC の産生増加およ び ${ }^{14} \mathrm{C}$-alkyl-acyl-GPC の 減少反応をより強力に促進し た。しかし $\mathrm{LTB}_{4}$ はなんの作用も示さなかった。一方 A 23187 非刺激の場合, 標識マクロファージの ${ }^{14} \mathrm{C}$-alkylacetyl GPC 産生に 5-HEPETE および 5-HETE 自体 はなんの影響も示さなかった。

\section{考 察}

alkyl-acetyl-GPC 合成は 2 つの過程を経るといわれ ている。すなおち，(1) phospholipase $\mathrm{A}_{2}$ の活性化によ り膜リン脂質よりの alkyl-acyl-GPC の水解反応による alkyl-lyso-GPC の生成と, (2) acetyl-CoA acetyltransferase による alkyl-llyso-GPC より alkyl-acetyl-GPC の 合成である。 


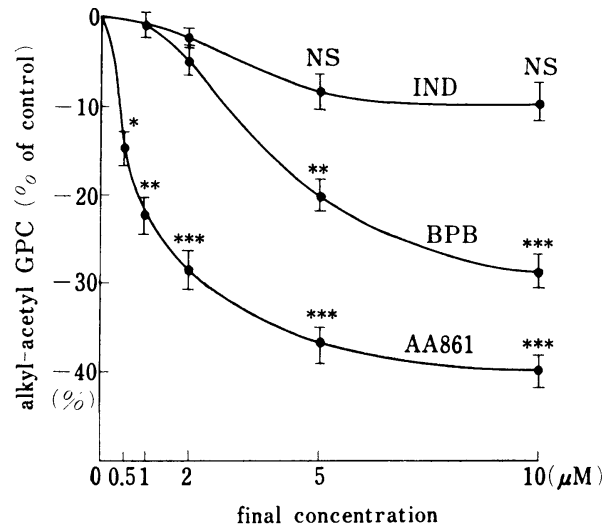

図 1 the effect of various inhibitors of arachidonate metabolism on ${ }^{14} \mathrm{C}$-alkyl-acetyl-GPC production in A 23187-stimulated macrophages

mean $\pm \mathrm{SD}, \mathrm{NS}$ : nots ignificant, $* \mathrm{P}<0.05$, ** $\mathrm{P}<0.01, * * * \mathrm{P}<0.001$

強力な phospholipase $\mathrm{A}_{2}$ 阻害剤である BPB により A 23187 刺激による標識マクロファージよりの ${ }^{14} \mathrm{C}$ alkyl-acetyl-GPC 産生が低下したことは, alkyl-acetyl -GPC 合成の最初の段階の阻害, すなわち alkyl-lyso -GPC よりの alkyl-lyso-GPC への転換が抑制されたた めと考えられる。 cyclooxygenase 阻害剂である indomethacin の添加で alkyl-acety-GPC 産生になんの影響もみ られなかったことは, AA の cylooxygenase 代謝産物は alkyl-acetyl-GPC 合成に重要な役割を果たしていない ことを意味していると考えられる。ラット腹腔マクロフ アージの主要なりポキシゲナーゼ代謝産物は, 5-lipoxygenase 代謝産物である 5-HETE， LTB 4 であり，5lipoxygenase の阻害剤である AA-861 により 5-HETE, $\mathrm{LTB}_{4}$ など 5-lipoxygenase の代謝産物のみその 産生が 抑制された。この成績は，Ashida らの報告と一致して お方 ${ }^{9)}$, AA-861 は 5-lipoxygenase の特異的阻害剤とい える. Siegel ら゙)は, 5-HPETE および 5-HETE がヒ トの promyelocytic leukemic cell line HL 60 におい て, chemotactic peptide または Ca-ionophore で刺激し た際，膜リン脂質よりの AA の遊離を促進したと述べ ている。したがってわれわれは，ラット腹腔マクロファ ージでの alkyl-acetyl-GPC 産生に 5-lipoxygenase 代謝 産物が重要な役割を果たしているのではないかと考え,

AA-861 で前処置したラット腹腔マクロファージにおけ る alkyl-acetyl-GPC の合成に及ぼす 5-lipoxygenase 代 謝産物の影響を調べてみた。

AA-861 は，A 23187 で刺激した標識マクロファージ での ${ }^{14} \mathrm{C}$-alkyl-acetyl-GPC 産生を用量依存性に抑制した が, この抑制効果は, 外因症に 5-HPETE, 5-HETE を

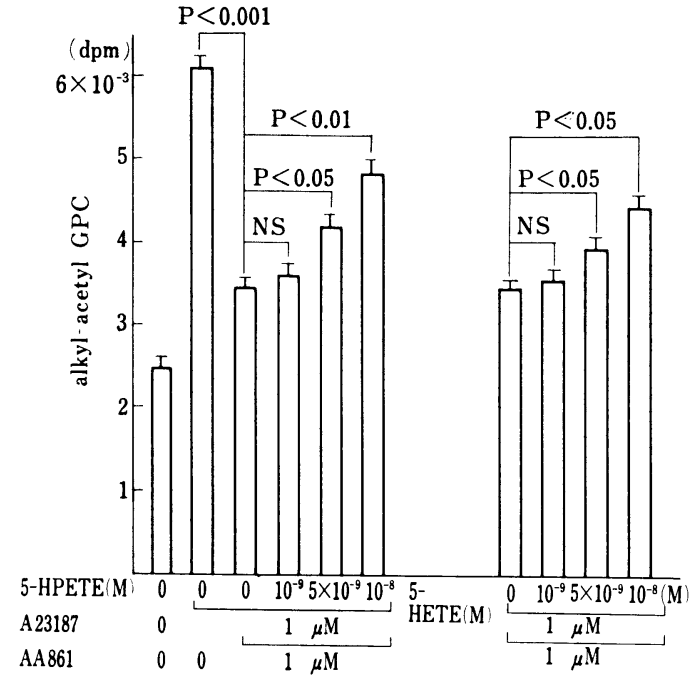

図 2 the effect of exogenously added 5-HPETE or 5-HETE on A 23187 -induced ${ }^{14} \mathrm{C}$-alkylacetyl-GPC production in AA-861 pretreated macrophages (mean $\pm \mathrm{SD}$ )

加えるとみられなくなった．特に 5-HPETE，5-HETE が減少すると alkyl-acyl-GPC の水解反応が抑兄られ， 5-HPETE，5-HETE が存在すると alkyl-acyl-GPC の 水解反応が促進されることは，5-HPETE および 5HETE（ただし $\mathrm{LTB}_{4}$ にはそのような作用はない）が膜 リン脂質に存在する alkyl-acyl-GPC の phospholipase $\mathrm{A}_{2}$ を介しこの水解反応に重要な役割を果たしているこ とを示唆しているものといえよう。

\section{文献}

1) Gemopoulos, C.A., et al.: J. Biol. Chem. 254: 9355, 1979.

2) Lin, A.H., et al.: J. Clin. Invest. 70: 1058, 1982.

3) O'Flaherty, J.T., et al.: Biochem. Biophys. Res. Commun. 111: 1, 1983.

4) Siegel, M.I., et al.: Biochem. Biophys. Res. Commun. 104: 874, 1982.

5）斉藤博幸 - 他：炎症 4：25, 1984.

6) Terao, S., et al.: Aqric. Biol. Chem. 45: 595, 1981.

7) Albert, D.H., et al.: J. Biol. Chem. 258: 97, 1982.

8) Bligh, E.G., et al.: Can. J. Biochem. Physiol. 37: 911, 1959.

9) Ashida, Y., et al.: Prostaglandins 26: 955, 1983. 